\title{
Gene Deletion
}

National Cancer Institute

\section{Source}

National Cancer Institute. Gene Deletion. NCI Thesaurus. Code C16606.

Any deletion mutation that occurs within a gene, including the $5^{\prime}$ and $3^{\prime}$ untranslated regions of the gene. 